\title{
Guest editorial: seismic microzonation of Central Italy following the 2016-2017 seismic sequence
}

\author{
Salomon Hailemikael ${ }^{1}$ (D) Sara Amoroso ${ }^{2,3}$ D $\cdot$ Iolanda Gaudiosi ${ }^{4}$ (D)
}

Received: 6 August 2020 / Accepted: 7 August 2020 / Published online: 17 August 2020 (c) Springer Nature B.V. 2020

The August 24th 2016 Mw 6.0 Amatrice earthquake struck Central Italy (http://cnt. rm.ingv.it/event/7073641; Chiaraluce et al. 2017), causing 298 casualties, hundreds of injured and almost complete destruction of the historical villages of Amatrice, Accumoli, Arquata del Tronto and Montegallo (Graziani et al. 2019; Sorrentino et al. 2018).

Unfortunately, the Amatrice earthquake was the beginning of a long-lasting seismic sequence of more than 50,000 events that culminated in the October 30th Mw 6.52016 Norcia earthquake, located about $20 \mathrm{~km} \mathrm{NW}$ of the Amatrice epicentre (http://cnt.rm.ingv. it/event/8863681). Moreover, the sequence included two Mw 5.4 and 5.9 earthquakes occurred on October 26th 2016 close to the Norcia epicentre (Valensise et al. 2017) and four earthquakes of $\mathrm{Mw}$ in the range 5.0-5.5 on January 18th 2017, about $20 \mathrm{~km} \mathrm{SE}$ of the Amatrice earthquake epicentre. This sequence left behind a widespread damage across the territory of 138 municipalities hosting about 582,000 inhabitants distributed over 10 Provinces in 4 Regions in Central Italy (https://sisma2016data.it/report-page/).

Soon after the emergency period, the Italian Government sponsored and funded structural and non-structural actions for the reconstruction of the territory struck by the seismic sequence (Dolce and Di Bucci 2018; Law of the 15th December 2016, n. 229 and Law of the 7th April 2017, n. 45). In particular, the Italian Government Commissioner for the reconstruction allocated about 5,6 million euros to an ambitious project for the Seismic Microzonation of the 138 municipalities (hereinafter, SM project).

In such a difficult circumstance, Seismic Microzonation was considered as an important tool for the reconstruction as it allows for the calculation of detailed seismic hazard estimates accounting for modifications of the expected ground shaking due to local geological conditions.

Salomon Hailemikael

salomon.hailemikael@enea.it

1 Agenzia Nazionale per le Nuove Tecnologie, l'Energia e lo Sviluppo Economico Sostenibile (ENEA), C.R. Frascati, Rome, Italy

2 Department of Engineering and Geology, University of Chieti-Pescara, Viale Pindaro, 42, 65129 Pescara, Italy

3 Istituto Nazionale di Geofisica e Vulcanologia, Rome, Italy

4 Consiglio Nazionale delle Ricerche, Istituto di Geologia Ambientale e Geoingegneria, Via Salaria Km 29,300 Monterotondo, Rome, Italy 
The SM project was ambitious because it involved the coordination of several local authorities at different levels, more than 100 researchers and 114 groups of local practitioners with the aim to complete the activities within 6 months from the beginning of the project (July 2017; Ordinance of the Italian Government Commissioner for the reconstruction of the 12th May 2017, n. 24).

The scientific coordination of the SM project was entrusted to the Centre for Seismic Microzonation and its Applications (CentroMS), an association of 25 Italian research Institutions and University departments, founded under the aegis of the National Research Council (CNR), which provides expertise in a wide spectrum: engineering seismology, applied geophysics, engineering geology and geotechnical earthquake engineering.

The goals of the SM project were:

- grounding post-earthquake urban plans on detailed seismic hazard estimates accounting for local geological/geotechnical conditions;

- providing site-dependent constraints for the design of new settlements and for interventions of retrofit and reconstruction.

Additional efforts were devoted to those municipalities that suffered almost complete destruction, namely Amatrice, Accumoli, Arquata del Tronto and Montegallo. These municipalities benefited of supplementary research activities carried out in the framework of the EmerTer project (EmerTer Project Working Group 2018), which was commissioned by the Italian Department of Civil Protection (Ordinance OCDPC of the 19th September 2016, n. 394 art. 14) to research Institutions and started in September 2016, before the widening of the seismic sequence. Data and results from EmerTer project, provided at the beginning of 2017, were merged with those of the SM project.

In order to maximize the impact of the SM project and ensure public accessibility to the maps and data storages, all the activities were carried out following the Italian Guidelines for Seismic Microzonation (SM-WG 2008); all the products (available at the link: https ://sisma2016data.it/microzonazione/) were realized according to specific Italian Standards (Technical Commission for Seismic Microzonation 2016) and by using dedicated software tools (https://github.com/CNR-IGAG/mzs-tools/wiki/MzS-Tools; last accessed 9th July 2018). The aforementioned Guidelines include shared procedures related to collection, archiving and processing of different types of data, whereas the Standards ensure homogeneous codifications and cartographic representation of results. Guidelines and standards are the results of the close cooperation between the Italian Department of Civil Protection and the Italian scientific community.

The current Italian regulations establish a gradual multi-level approach, with 3 levels of increasing detail and, in turn, increasing commitment and cost of Seismic Microzonation studies from the preliminary (SM1) to the advanced (SM3) levels (these studies of the Italian territory are available at the link: www.webms.it). According to the current approach, Seismic Microzonation studies with the maximum degree of detail (SM3) were carried out for the 138 municipalities. They focused on the estimation of seismic ground-motion amplification and evaluation of representative seismic loads for each homogeneous area identified in map. Seismically-induced ground instabilities (ground surface faulting, liquefaction and, excepting for few test areas, landslides) were only considered for identification and mapping: no geotechnical characterization of these conditions has been provided.

The experience gained during the SM project was extremely useful for both the scientific community and the practitioners in charge of the studies. In fact, during the project, the participants had the opportunity to address a broad range of topics of scientific 
interest, ranging from seismic ground-motion observations to ground-motion simulation. In addition, the SM project promoted knowledge transfer from CentroMS experts to the practitioner community through the organization of dedicated courses aimed at presenting the specific protocols for geophysical acquisition and processing, numerical modelling and seismic microzonation mapping at the beginning of the project. SM project also contributed to participants' skills training and raising seismic hazard awareness among the population who was informed of the on going activities.

Furthermore, procedures and protocols adopted in the project may contribute to the definition of best practices and standards for Seismic Microzonation at the Euro-Mediterranean scale. Sharing the experience gained within the project may also contribute to the implementation of the EU's international commitments towards disaster reduction and preparedness, such as those individuated by the Sendai Framework for Disaster Risk Reduction 2015-2030 (https://www.undrr.org/publication/sendai-framework-disas ter-risk-reduction-2015-2030).

This Special Issue of the Bulletin of Earthquake Engineering is a compilation of 12 papers that aims at the description of the activities carried out for this project, which provides further contribution to the improvement of earthquake engineering knowledge: in the first 8 papers, general approaches common to the whole SM project are described, whereas the last 4 papers provide insights on specific case-studies.

Seismic Microzonation has a relatively long history in Italy that dates back to the 1976 Friuli earthquake (Brambati et al. 1980). The current approach to Seismic Microzonation originated in 2009, when the Italian Government funded the Italian Program for Seismic Prevention (Dolce 2012). The paper by Moscatelli et al. (2020) describes in detail this Program as well as the current Italian Seismic Microzonation approach, which is gradual and multi-level to promote its extensive application. The authors depicted goals, methods and products and provided a clear description of the organization of the project devoted to the Seismic Microzonation activities supporting reconstruction in Central Italy after the 2016-2017 seismic sequence.

SM3 analysis requires as basic information layer the definition of the local engineering-geological model, which summarizes the site-specific information on the distribution of the engineering-geological units (thereinafter gt-units) distinguished in the subsurface on the basis of their geological, geotechnical and geophysical properties. Starting from a brief description of the geological-geomorphological setting of Central Italy, the paper by Amanti et al. (2020a) provides the methodological framework by which the engineering-geological model is retrieved from standard geological information. The authors provided an archive of gt-units in Central Italy and developed a statistical analysis of the shear wave velocity (Vs) distribution among the identified gt-units. They found that Vs estimations well differentiate among such units if burial depth and unit location in the different geological and morphostructural domains of the region are accounted for.

Vs is a well-known key parameter controlling ground-motion amplification and its variability (e.g. Semblat and Pecker 2009, among many others). Another important site parameter related to both stiffness distribution in the subsurface and depth of the seismic bedrock is the fundamental resonance frequency (f0). The paper by Caielli et al. (2020) describes how a large number of geophysical data were acquired in a short time during the project to evaluate the Vs and f0 distributions in the investigated municipalities. The authors provided description of the guidelines implemented for geophysical surveys and reported about the encountered problems and the identified weak points in data acquisition and result interpretations that required improvements or cautions. 
Final SM3 map is built based on the results of numerical simulations of seismic wave propagation within engineering-geological models of the subsoil. Such simulations require to associate suitable nonlinear soil behaviour to the identified gt-units and to select adequate forcing seismic actions (seismic input) at their base. The paper by Ciancimino et al. (2019) presents the results of almost 80 cyclic and dynamic laboratory tests carried out by several Italian universities for the above-mentioned Seismic Microzonation studies. The authors presented in-depth data interpretation, also in comparison with field measurements. In particular, the huge dataset was used to develop a predictive model for soil nonlinear curves according to plasticity index, mean effective confining stress, and loading frequency. The calibrated model represents a useful reference to model nonlinear stress-strain behaviour of Central Italy fine-grained soils, necessary to perform site-specific ground response analyses.

A key role in seismic input selection has been played by integrated infrastructures, such as temporary seismic networks and data repositories. Luzi et al. (2019) fully exploited the dataset stored in the European Strong Motion Database (ESM, http://esm.mi.ingv.it; Luzi et al. 2016) and its Italian node (Italian Accelerometric Archive, ITACA, http://itaca.mi. ingv.it; Luzi et al. 2008). Among thousands of waveforms, the authors performed the selection of 39 records that can be combined to build the 138 suites of 7 accelerograms, one for each municipality subjected to SM3, to be used for numerical simulations. Selection was based on specific criteria and records, which were compatible with the chosen reference seismic hazard level (peak ground acceleration with $10 \%$ exceedance probability in 50 years). Notably, waveforms acquired by the temporary seismic networks deployed in the epicentral region of the 24th August 2016 Central Italy Earthquake constituted a significant number of the selected records.

Seismological data are undoubtedly a fundamental resource of information about ground-motion level distribution. In SM3 studies, ground-motion records can be used to perform empirical ground response analysis and calibrate numerical models of seismic wave propagation. The paper by Priolo et al. (2019) describes the results of a systematic analysis of data recorded in about 15 years at about 180 seismic monitoring stations, both temporary and permanent installations, located in or close the 138 municipalities subjected to SM3 studies in Central Italy. The authors used a uniform methodological approach to analyse earthquake and noise recordings for deriving site response parameters, such as spectral amplification curves, fundamental resonance frequencies, site-specific response spectra, and average amplification factors. The results, collected and homogeneously summarized in site-specific forms, showed that the urbanized territory in Central Italy is generally prone to seismic amplification.

According to the Italian approach, the results of all information gathered in the studies are summarized in a Seismic Microzonation map, which is drawn based on the spatial distribution of estimated ground-motion amplification effects. Pergalani et al. (2019) provided an overview of the main results and critical issues of the Seismic Microzonation procedure applied to the 138 municipalities of Central Italy. A procedure to obtain SM3 maps with the selection of suitable amplification factors to be used in the identification of areas seismically homogeneous was proposed starting from 1D/2D ground response analyses. The paper also remarks some uses of Seismic Microzonation products in supporting seismic design, provided that the Italian building code prescriptions and the SM project studies refer to different scales.

A new proposal on the use of Seismic Microzonation results is included in the paper by Mori et al. (2019). The authors proposed an operational definition of seismic hazard in which results from the Seismic Microzonation activities in Italy are embedded. The 
paper also shows how the inclusion of a damage constrained parameter, named $\mathrm{H}_{\mathrm{SM}}$, in urban planning and seismic design may help reaching different outcomes. In particular, the authors discussed the effective contribution of $\mathrm{H}_{\mathrm{SM}}$ at: (i) helping decision makers to highlight priority intervention areas; (ii) defining best practices for existing structures, such as specific response studies, where higher overall seismic hazard values are expected.

The paper by Martino et al. (2019) introduces the section of the Special Issue devoted to the discussion of specific case studies. In this paper, the authors presented the application of the PARSIFAL (Probabilistic Approach to pRovide Scenarios of earthquake-Induced slope FAiLures, Esposito et al. 2016) method to the Accumoli area. This method allows for obtaining probabilistic slope failure scenarios depending on seismic input and saturation conditions. It handles both rock- and earth-slides with different failure mechanism, distinguishing among first-induced and reactivated landslides by earthquakes. Considering a seismic action with return period of 475 years and a critical displacement threshold of $10 \mathrm{~cm}$ for earth-slides and $5 \mathrm{~cm}$ for rock-slides, the authors found that up to $2 \%$ of the entire municipal territory correspond to already unstable or landslide-prone areas. However, their in-depth analysis led to a reduction of $22 \%$ of the previously distinguished instability areas mapped on the basis of simplified methods.

The paper by Amanti et al. (2020b) focuses on the Seismic Microzonation activities conducted during the emergency and post-emergency phases in Pescara del Tronto, which suffered almost complete destruction after the Amatrice earthquake. The authors gathered all geological, geotechnical and geophysical data useful for outlining a sound subsurface model in the area and combined a rapid assessment of the landslide susceptibility and ground response analysis to locate areas for provisional settlements. In particular, the authors found that a significant ground-motion amplification may have characterized the area of the old Pescara del Tronto settlement.

Milana et al. (2019) illustrate the results of seismological and geophysical investigations performed in Amatrice village, in the emergency phases following the Mw 6.0 event of August 24th 2016. Data from weak- and strong-motions and from ambient vibrations have been used to better understand the distribution of amplification factors in the investigated area. The data analyses revealed a diffused amplification effect, which reaches its maximum values in downtown area with a resonant frequency of about $2 \mathrm{~Hz}$, in agreement with the distribution of earthquake damages. The presented seismological and geophysical dataset allowed for better constraining the models used in the numerical simulations for Seismic Microzonation studies.

Finally, Pagliaroli et al. (2019) present the results of the ground response analyses performed for 5 complex geological and morphological conditions, selected within the SM project. Implications are then deduced for Seismic Microzonation studies in similar geological and morphological conditions: (1) for slope configurations, 1D analyses could be enough to provide reliable estimation of amplification factors, despite the presence of an inclined bedrock; (2) for ridge configurations, 2D ridge resonance governs the seismic response for periods corresponding to wavelengths comparable with the base size of the relief, exceeding the simplified topographic amplification factors proposed by technical codes; (3) for valley configurations, 2D analyses result mandatory to properly quantify amplification factors at the edge of a large valley, while in the centre of a large valley $2 \mathrm{D}$ effects can be neglected.

The 12 papers collected in this Special Issue of the Bulletin cover a broad range of scientific fields and address methodological and practical issues related to Seismic Microzonation activities. These papers by no means exhaust the research on the field, but they certainly represent the State of the Art at the Italian level. 
All the work presented in this volume would have not been possible without the financial support of the Italian Government Commissioner for the reconstruction to whom we would like to extend our thanks.

As Guest Editors of this Special Issue, we would like to thank the authors for their interesting contributions and the international panel of reviewers for their careful comments which helped improving the original submissions. Most importantly, we would like to express our sincere gratitude to the Editor of the Bulletin of Earthquake Engineering, Prof. Atilla Ansal, for its fundamental guidance in producing this Issue and to Petra Van Steenbergen and the Technical Staff of Springer for the continuous assistance throughout the editorial process. We would also like to thank Prof. Gabriele Scarascia Mugnozza, Prof. Dario Albarello and Dr. Massimiliano Moscatelli for providing useful comments that improved the initial version of this Guest Editorial.

This Special Issue is dedicated to the memory of Prof. Marco Mucciarelli, who was a passionate researcher and leading figure within the scientific community working in the seismic risk assessment field. This Issue is also a tribute to the memory of Tiziana Lo Presti, Civil Protection Official who passed away in Amatrice the night of 24th August 2016, and all the other victims of the 2016-2017 Central Italy sequence.

\section{References}

Amanti M, Muraro C, Roma M, Chiessi V, Puzzilli L, Catalano S, Romagnoli G, Tortorici G, Cavuoto G, Albarello D, Fantozzi PL, Paolucci E, Pieruccini P, Caprari P, Mirabella F, Della Seta M, Esposito C, Di Curzio D, Francescone M, Pizzi A, Macerola L, Nocentini M, Tallini M (2020a) Geological and geotechnical models definition for 3rd level seismic microzonation studies in Central Italy. Bull Earthq Eng. Special Issue on "Seismic Microzonation of Central Italy following the 2016-2017 Seismic Sequence". First Online: 18th April 2020. https://doi.org/10.1007/s10518-020-00843-x

Amanti M, Puzzilli LM, Chiessi V, Roma M, D’Orefice M, Fiorenza D, Troccoli A, Ferri F (2020b) The Seismic Microzonation of Pescara del Tronto (Central Italy) during and after the 2016 Central Italy Earthquake sequence. Bull Earthq Eng. Special Issue on "Seismic Microzonation of Central Italy following the 2016-2017 Seismic Sequence"

Caielli G, de Franco R, Di Fiore V, Albarello D, Catalano S, Pergalani F, Cavuoto G, Cercato M, Compagnoni M, Facciorusso J, Famiani D, Ferri F, Imposa S, Martini G, Paciello A, Paolucci E, Passeri F, Piscitelli S, Puzzilli LM, Vassallo M (2020) Extensive surface geophysical prospecting for seismic microzonation. Bull Earthq Eng. Special Issue on "Seismic Microzonation of Central Italy following the 2016-2017 Seismic Sequence”, First Online: 27th May 2020. https://doi.org/10.1007/s10518-02000866-4

Chiaraluce L, Di Stefano R, Tinti E, Scognamiglio L, Michele M, Casarotti E, Catteneo M, De Gori P, Chiarabba C, Monachesi G, Lombardi A, Valoroso L, Latorre D, Marzorati S (2017) The 2016 Central Italy seismic sequence: a first look at the mainshocks, aftershocks, and source models. Seismol Res Lett 88(3):757-771. https://doi.org/10.1785/0220160221

Ciancimino A, Lanzo G, Alleanza GA, Amoroso S, Bardotti R, Biondi G, Cascone E, Castelli F, Di Giulio A, D’Onofrio A, Foti S, Lentini V, Madiai C, Vessia G (2019) Dynamic characterization of finegrained soils in Central Italy by laboratory testing. Bull Earthq Eng. Special Issue on "Seismic Microzonation of Central Italy following the 2016-2017 Seismic Sequence”. First Online: 10th April 2019. https://doi.org/10.1007/s10518-019-00611-6

Dolce M (2012) The Italian national seismic prevention program. In: Proceedings of 15 th world conference on earthquake engineering. Lisbon, September pp 24-28. https://www.civil.ist.utl.pt/ mlopes/conte udos/SISMOS/DOLCE.pdf

Dolce M, Di Bucci D (2018) The 2016-2017 Central Apennines seismic sequence: analogies and differences with recent Italian earthquakes. In: Pitilakis K (ed) Recent advances in earthquake engineering in Europe. ECEE 2018. Geotechnical, geological and earthquake engineering, vol 46. Springer, Cham

EmerTer Project Working Group (2018) Report of the: "Accordo ai sensi dell'art. 15 Legge 7 agosto 1990 n. 241, e dell'art.6 della Legge 24 febbraio 1992, n. 225 tra il Dipartimento della Protezione Civile e 
l'Istituto di Geologia Ambientale e Geoingegneria del Consiglio Nazionale delle Ricerche per il supporto alle attività della DICOMAC di Rieti e della Struttura di Missione, Prot. CNR IGAG n. 1484 del 17/05/2017”, Prot. CNR IGAG n. 359 del 30/01/2018 (in Italian)

Esposito C, Martino S, Pallone F, Martini G, Romeo R (2016) A methodology for a comprehensive assessment of earthquake-induced landslide hazard, with an application to pilot sites in Central Italy. In: Landslides and engineered slopes. Experience, theory and practice, vol 2, pp 869-877. Taylor and Francis Inc

Brambati A, Faccioli, E, Carulli GB, Cucchi F, Onofri R, Stefanini S, Ulcigrai F (1980) Studio di microzonizzazione sismica dell'area di Tarcento, edited by Regione Autonoma Friuli Venezia-Giulia (in italian)

Graziani L, del Mese S, Tertulliani A, Arcoraci L, Maramai A, Rossi A (2019) Investigation on damage progression during the 2016-2017 seismic sequence in Central Italy using the European Macroseismic Scale (EMS-98). Bull Earthq Eng 17:5535-5558. https://doi.org/10.1007/s10518-019-00645-w

Luzi L, Hailemikael S, Bindi D, Pacor F, Mele F, Sabetta F (2008) ITACA (ITalian ACcelerometric Archive): a web portal for the dissemination of italian strong-motion data. Seismol Res Lett 79(5):716722. https://doi.org/10.1785/gssrl.79.5.716

Luzi L, Pacor F, Lanzano G, Felicetta C, Puglia R, D’Amico M (2019) 2016-2017 Central Italy seismic sequence: strong-motion data analysis and design earthquake selection for seismic microzonation purposes. Bull Earthq Eng. Special Issue on "Seismic Microzonation of Central Italy following the 20162017 Seismic Sequence". First Online: 19th July 2019. https://doi.org/10.1007/s10518-019-00676-3

Martino S, Battaglia S, D’Alessandro F, Della Seta M, Esposito C, Martini G, Pallone F, Troiani F (2019) Earthquake-induced landslide scenarios for seismic microzonation: application to the Accumoli area (Rieti, Italy). Bull Earthq Eng. Special Issue on "Seismic Microzonation of Central Italy following the 2016-2017 Seismic Sequence”. First Online: 26th March 2019. https://doi.org/10.1007/s10518-01900589-1

Milana G, Cultrera G, Bordoni P, Bucci A, Cara F, Cogliano R, Di Giulio G, Di Naccio D, Famiani D, Fodarella A, Mercuri A, Pischiutta M, Pucillo S, Riccio G, Vassallo M, (2019) Local site effects estimation at Amatrice (Central Italy) through seismological methods. Bull Earthq Eng. Special Issue on "Seismic Microzonation of Central Italy following the 2016-2017 Seismic Sequence". First Online: 21st February 2019. https://doi.org/10.1007/s10518-019-00587-3

Mori F, Gaudiosi I, Tarquini E, Bramerini F, Castenetto S, Naso G, Spina D (2019) HSM: a synthetic damage-constrained seismic hazard parameter. Bull Earthq Eng. Special Issue on "Seismic Microzonation of Central Italy following the 2016-2017 Seismic Sequence”. First Online: 03rd July 2019. https://doi. org/10.1007/s10518-019-00677-2

Moscatelli M, Albarello D, Scarascia Mugnozza G, Dolce M (2020) The Italian approach to seismic microzonation. Bull Earthq Eng. Special Issue on "Seismic Microzonation of Central Italy following the 2016-2017 Seismic Sequence”. First Online: 14th May 2020. https://doi.org/10.1007/s10518-02000856-6

Pagliaroli A, Pergalani F, Ciancimino A, Chiaradonna A, Compagnoni M, de Silva F, Foti S, Giallini S, Lanzo G, Lombardi F, Luzi L, Macerola L, Nocentini M, Pizzi A, Tallini M, Teramo C (2019) Site response analyses for complex geological and morphological conditions: relevant case-histories from 3rd level seismic microzonation in Central Italy. Bull Earthq Eng. Special Issue on "Seismic Microzonation of Central Italy following the 2016-2017 Seismic Sequence”. First Online: 15th April 2019. https://doi.org/10.1007/s10518-019-00610-7

Pergalani F, Pagliaroli A, Bourdeau C, Compagnoni M, Lenti L, Lualdi M, Madiai C, Martino S, Razzano R, Varone C, Verrubbi V (2019) Seismic microzoning map: approaches, results and applications after the 2016-2017 Central Italy seismic sequence. Bull Earthq Eng. Special Issue on "Seismic Microzonation of Central Italy following the 2016-2017 Seismic Sequence". First Online: 104th May 2019. https ://doi.org/10.1007/s10518-019-00610-7

Priolo E, Pacor F, Spallarossa D, Milana G, Laurenzano G, Romano MA, Felicetta C, Hailemikael S, Cara F, Di Giulio G, Ferretti G, Barnaba C, Lanzano G, Luzi L, D’Amico M, Puglia R, Scafidi D, Barani S, De Ferrari R, Cultrera G (2019) Seismological analyses of the seismic microzonation of 138 municipalities damaged by the 2016-2017 seismic sequence in Central Italy. Bull Earthq Eng. Special Issue on "Seismic Microzonation of Central Italy following the 2016-2017 Seismic Sequence". First Online: 08th June 2019. https://doi.org/10.1007/s10518-019-00652-x

Luzi L, Puglia R, Russo E, ORFEUS WG5 (2016) Engineering Strong Motion Database, version 1.0. Istituto Nazionale di Geofisica e Vulcanologia. Observatories \& Research Facilities for European Seismology. https://doi.org/10.13127/esm

Semblat JF, Pecker A (2009) Waves and vibrations in soils: earthquakes, traffic, shocks, construction works, I. Press (Editor). IUSS Press, Pavia 
SM-WG (2008) Guidelines for seismic microzonation. In: Conference of regions and autonomous provinces of Italy-Civil Protection Department, Rome, vol 3 and DVD. English edition published online in 2015. https://www.centromicrozonazionesismica.it/it/download/category/9-guidelines-for-seismicmicrozon ation

Sorrentino L, Cattari S, da Porto F, Magenes G, Penna A (2018) Seismic behaviour of ordinary masonry buildings during the 2016 Central Italy earthquakes. Bull Earthq Eng. https://doi.org/10.1007/s1051 8-018-0370-4

Technical Commission for Seismic Microzonation (2016) Graphic and data archiving standards. Version 4.0b. Department of Civil Protection of the Presidency of the Council of Ministers. Rome. https:// www.centromicrozonazionesismica.it/it/download/category/31-standardms-4 (Italian version)

Valensise G, Tarabusi G, Guidoboni E, Ferrari G (2017) The forgotten vulnerability: a geology- and historybased approach for ranking the seismic risk of earthquake-prone communities of the Italian Apennines. Int J Disaster Risk Reduct. https://doi.org/10.1016/j.ijdrr.2017.09.014

Publisher's Note Springer Nature remains neutral with regard to jurisdictional claims in published maps and institutional affiliations. 